Ibn Al-Haitham Jour.for Pure \&Appl.Sci. 33 (3) 2020

Ibn Al Haitham Journal for Pure and Applied Science

Journal homepage: http://jih.uobaghdad.edu.iq/index.php/j/index

\title{
Synthesis and Antibacterial Activity of PEG Polycyclic Acetal Metal Complex/ PVA Polymer Blend Film
}

\author{
Maha A.Younus \\ Media Umran Ali \\ Department of Chemistry, College of Education for Pure Science Ibn Al-Haitham, University of \\ Baghdad, Baghdad, Iraq. \\ ma2004ha@yahoo.com \\ mydyamran11@gmail.com \\ Article history: Received 12 December 2019, Accepted 16 February 2020, Published \\ in July 2020.
}

Doi: $10.30526 / 33.3 .2472$

\begin{abstract}
Polyacetal was synthesized from the reaction of Polyethylene glycol with 4- dimethyl aminobenzaldehyde. Polymer metal complex was synthesized by the reaction with $\mathrm{Ag}^{+}$; polymer blend with polyvinyl alcohol was synthesized solution casting technique. All synthesized compounds were characterized by FT-IR in addition to the antimicrobial activity. The FT-IR spectra indicate the formation of the polyacetal. The DSC results indicate the thermal stability regarding the synthesized polymer blends. The synthesized polyacetal, its metal complex and PA blend against four types of bacteria (gram+ve) Staphylococcus aureas, Bacillus subtilis and (gram -ve) Klebsiella pneumoniae, Escherichia Coli were evaluated. The results revealed that the polyacetal-Ag complex has the greater potential against all kinds of bacteria than polyacetal and polymer blend.
\end{abstract}

Keywords: PEG, Polycyclic acetal, Antimicrobial Polymers, polymer Blend

\section{Introduction}

The microbial infections can be considered to be a high concern due to the fact that they are a major cause of morbidity, particularly in the health-care institutions, in which individuals are commonly more exposed $[1,2]$. Such a fact is mainly due to the persistence regarding the potentially pathogenic microbes (fungi, viruses, and bacteria) in different locations, like sanitation facilities, medical devices, textiles, health care products and systems of water purification [3,4]. Polyethylene glycol (PEG) is a synthetic material with a wide range of clinical applications, as its functions can be modified by regulating its physical and chemical properties of graft-related materials [5]. Polyacetal is considered to be one of the few materials with possible application in producing elements that increase the flow of blood in blood vessels (stents) and that slowly degrade in the body and release incorporated drugs. The most straight forward polycyclic acetal medical application, that is examined today. 
Uses material for manufacturing orthodontic brackets [6]. Polymer blends have been physical mixtures related to at least two polymers without/with chemical bonding between them. The aim related to the polymer blending is to achieve products which are commercially viable via unique properties or low costs in comparison to other approaches can provide [7]. The present research work polyacetal was initially synthesized by the reaction of PEG with $\mathrm{N}$, Ndimethyl aminobenzaldehyde, polymer metal complex was prepared from the reaction of polyacetal with Ag and PVA added to form polyacetal-Ag /PVA polymer blend. The prepared polymer, its metal complex and the polymer blend were characterized and its biological activity was tested .

\section{Experimental}

Poly (ethylene glycol) M.W8000 has been purchased from HIMEDIA, also all the solvents and reagents have been purchased from $\mathrm{BDH}$ and utilized without any purification.

\subsection{Synthesis of PEG poly cyclic acetal [8]}

PEG $(0.1875 \mathrm{mmol})$ has been dissolved in $(25 \mathrm{~mL}) \mathrm{DMSO}$ at $50^{\circ} \mathrm{C}$ and added with mixing, the solution has been mixed in $(250 \mathrm{~mL})$ round bottle benzene and ethanol with ratio 80:20 with two drops of $\mathrm{HCl}$ conc. After that, the aldehyde (1.2 $\mathrm{g}, 1 \mathrm{mmol})$ of (4dimethylaminobenzaldehyde) was added to a solution, and stirred magnetically at $50^{\circ} \mathrm{C}$ for $24 \mathrm{~h}$, the resulting mixture has been neutralized by adding two drops of $\mathrm{NaOH}(5 \mathrm{~N})$ solution. The crude product has been washed with the acetone then distilled water many times. The products have been dried at a $\left(40^{\circ} \mathrm{C}\right)$ for a period of $12 \mathrm{~h}$. Synthetic route related to target compounds demonstrated in Figure1.

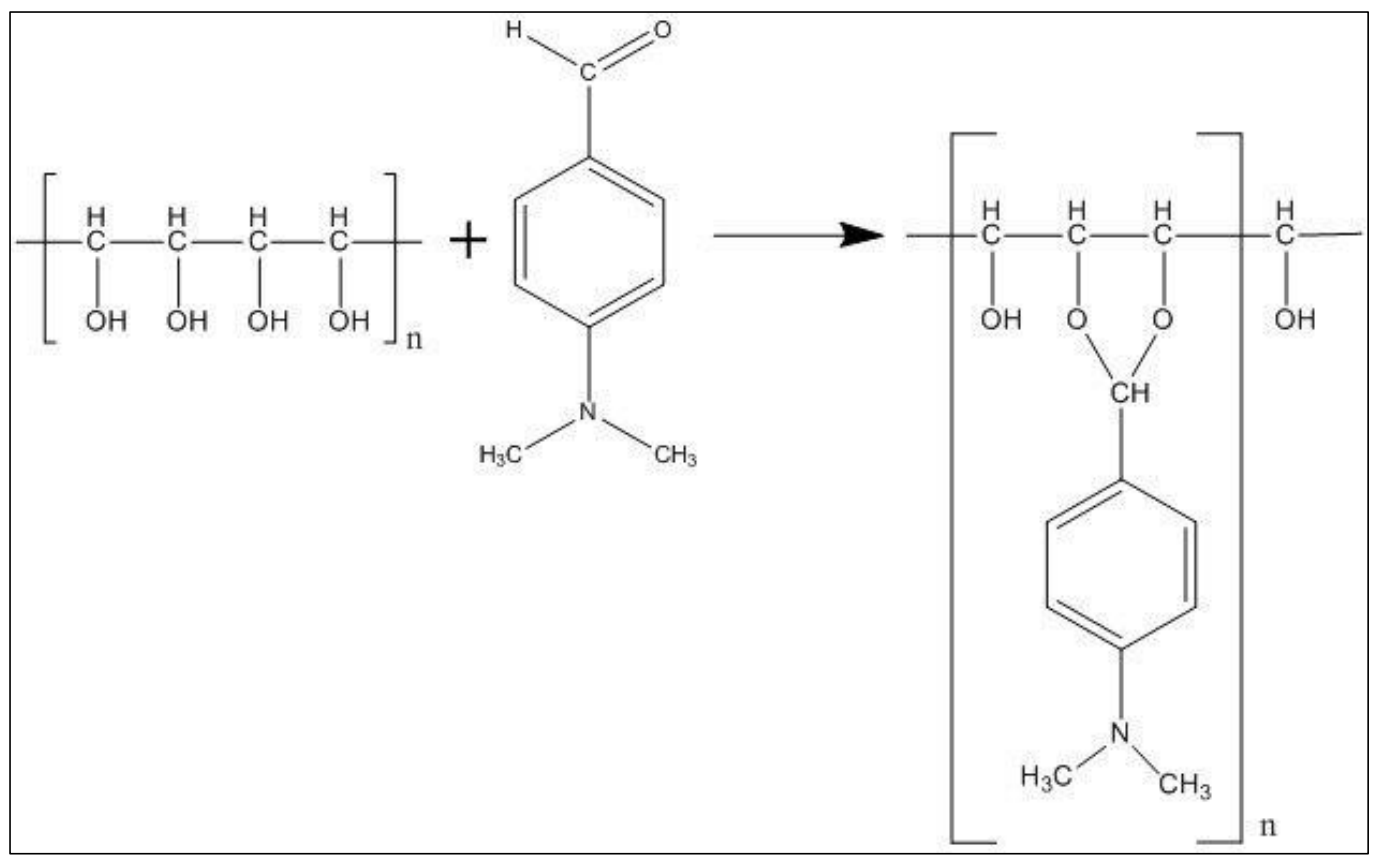

Figure 1. PEG modified with aldehyde. 


\subsection{Synthesized of polycyclic acetal metal complexes [9]}

$(0.6 \mathrm{~g}, 1 \mathrm{Mmol})$ regarding the modified polymer ligand was mixed with $(0.2 \mathrm{~g}, 1 \mathrm{Mmol}$ AgNO3) was dissolved in $20 \mathrm{mLof}$ DMSO with continuously stirring, after that the mixture was heated at $60^{\circ} \mathrm{C}$ for 12 hours. Upon cooling, the complex was washed with ethanol, then dried at $60^{\circ} \mathrm{C}$ in vacuum 24 hours. Synthetic route related to the target compound displayed Figure2.

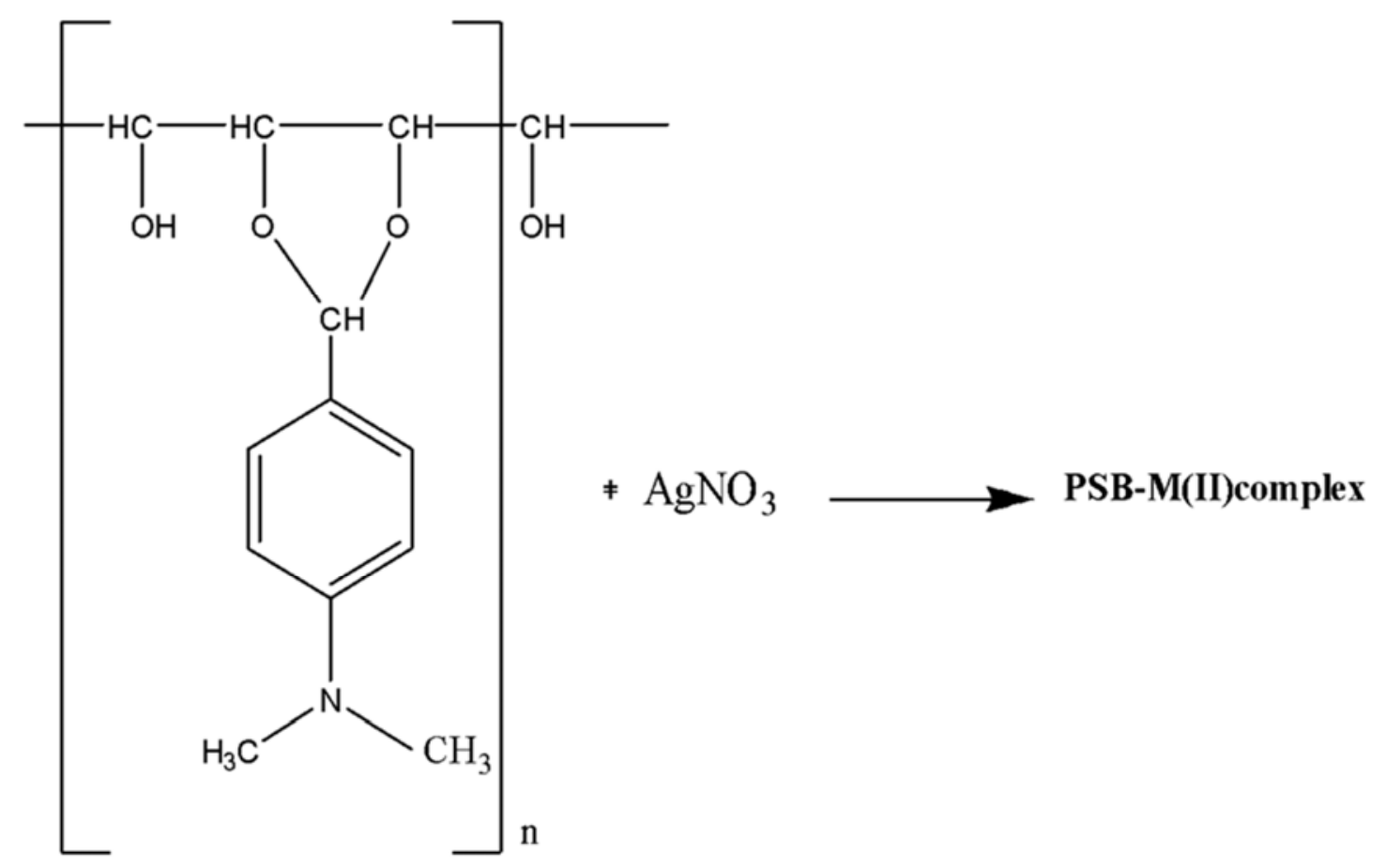

Figure 2. Preparation of polymer metal complexes.

\subsection{Preparation of polymer blends:}

Polymer films was prepared by casting approach solution. The polycyclic acetal metal complex solution was prepared by dissolving 0.6 gm polyacetal in $(25 \mathrm{ml}) \mathrm{DMSO}$ at $50^{\circ} \mathrm{C}$ with stirring (5gm) PVA was dissolved in a hot water for creating 5\% polymer solution. The two polymer solutions were mixed at different ratios. PVA weight fraction was different for obtaining series of blends with $(0-100 \% \mathrm{wt} / \mathrm{wt})$ PVA in resulting solution as it can be seen in Table1. 
Ibn Al-Haitham Jour.for Pure \&Appl.Sci. 33 (3) 2020

Table1. The weight fraction of PVA Polymer blend.

\begin{tabular}{|c|c|c|}
\hline Polymer blend & PA\% & PVA\% \\
\hline B1 & 25 & 75 \\
\hline B2 & 50 & 50 \\
\hline B3 & 75 & 25 \\
\hline B1Ag & 25 & 75 \\
\hline B2Ag & 50 & 50 \\
\hline B3Ag & 75 & 25 \\
\hline
\end{tabular}

Physical properties of the prepared polyacetal, its metal complex and polymer blend are shown in Table 2.

Table 2. Physical properties of prepared polymers.

\begin{tabular}{|c|c|}
\hline Symbol & Colors \\
\hline PEG & White \\
\hline PA & White \\
\hline B(PA-PVA) & Light Green \\
\hline PA-Ag & Dark Brown \\
\hline B1Ag & Dark Brown \\
\hline B2Ag & Dark Brown \\
\hline B3Ag & Dark Brown \\
\hline
\end{tabular}

\section{Results and Discussion}

Poly cyclic acetal-Ag metal complex was synthesized from the reaction of PEG with 4-N, $\mathrm{N}$ dimethyl aminobenzaldehyde and characterized by FTIR, antibacterial activity.

\subsection{FTIR - characterization of PEG cyclic acetal, PVA polymer blend:}

PEG polyacetal was synthesized from reaction of PEG with para dimethyl amino benzaldehyde. The FTIR spectrum of ligand (PA) Figure 3. Displayed bands at $3471 \mathrm{~cm}$ assigned to $(\mathrm{O}-\mathrm{H}$ stretching vibration) the band at $(2889,2736 \mathrm{~cm})$ assigned to $(\mathrm{C}-\mathrm{H}$ symmetric and asymmetric stretching), $(1111 \mathrm{~cm}-1)$ for $(\mathrm{C}-\mathrm{O}-\mathrm{H}$ stretching $),(3100) \mathrm{cm}-1$ due to $(\mathrm{C}-\mathrm{H}$ aromatic stretching $),(1342 \mathrm{~cm}-1)$ and $(1468 \mathrm{~cm}-1)$ for $(\mathrm{C}-\mathrm{N}),(1153 \mathrm{~cm}-1)$ for $(\mathrm{C}-\mathrm{O}-\mathrm{C})$ acetal group.

FT-IR spectrum regarding blend polymers, Figure 4. Showed a broad absorption band in range $3402 \mathrm{~cm}-1$ corresponding to $(\mathrm{O}-\mathrm{H}$ stretching vibration), $2918 \mathrm{~cm}-1$ is for $(\mathrm{C}-\mathrm{H}$ symmetric stretch), $(1666 \mathrm{~cm}-1)$ for $(\mathrm{C}=\mathrm{C}$ aromatic $)(1371 \mathrm{~cm}-1)$ and $(1439 \mathrm{~cm}-1)$ for $(\mathrm{C}-\mathrm{N})$ $\mathrm{N}, \mathrm{N}$ di methyl group, $(\mathrm{C}-\mathrm{O})$ acetal group of ligand at $(1167 \mathrm{~cm}-1)$ and $(1109 \mathrm{~cm}-1)$ for $(\mathrm{C}-$ $-\mathrm{O}-\mathrm{H})$ stretching .

FTIR spectra of the PVA/PA-Ag complex Figure 5. Showed broad band at range of (3425cm-1) for (O-H stretching vibration), as well as band at range of $(2991 \mathrm{~cm}-1)$, due to stretching vibration of $(\mathrm{C}-\mathrm{H})$ aliphatic, $(1167 \mathrm{~cm}-1)$ for $(\mathrm{C}-\mathrm{O}-\mathrm{C})$ acetal group and 
Ibn Al-Haitham Jour.for Pure \&Appl.Sci. 33 (3) 2020

(1109cm-1) for $(\mathrm{C}-\mathrm{O}-\mathrm{H}$ stretching $)$, bands at $(810-995 \mathrm{~cm}-1)$ indicated to coordinates water (aqua) and bands at the range of $(596-400 \mathrm{~cm}-1)$ attributed to the metal coordination to the ligand, $(1369 \mathrm{~cm}-1),(1360 \mathrm{~cm}-1)$ owing to the stretching vibration of (Ag-ONO2) symmetrical and asymmetrical for the PVA/PA-Ag complex.

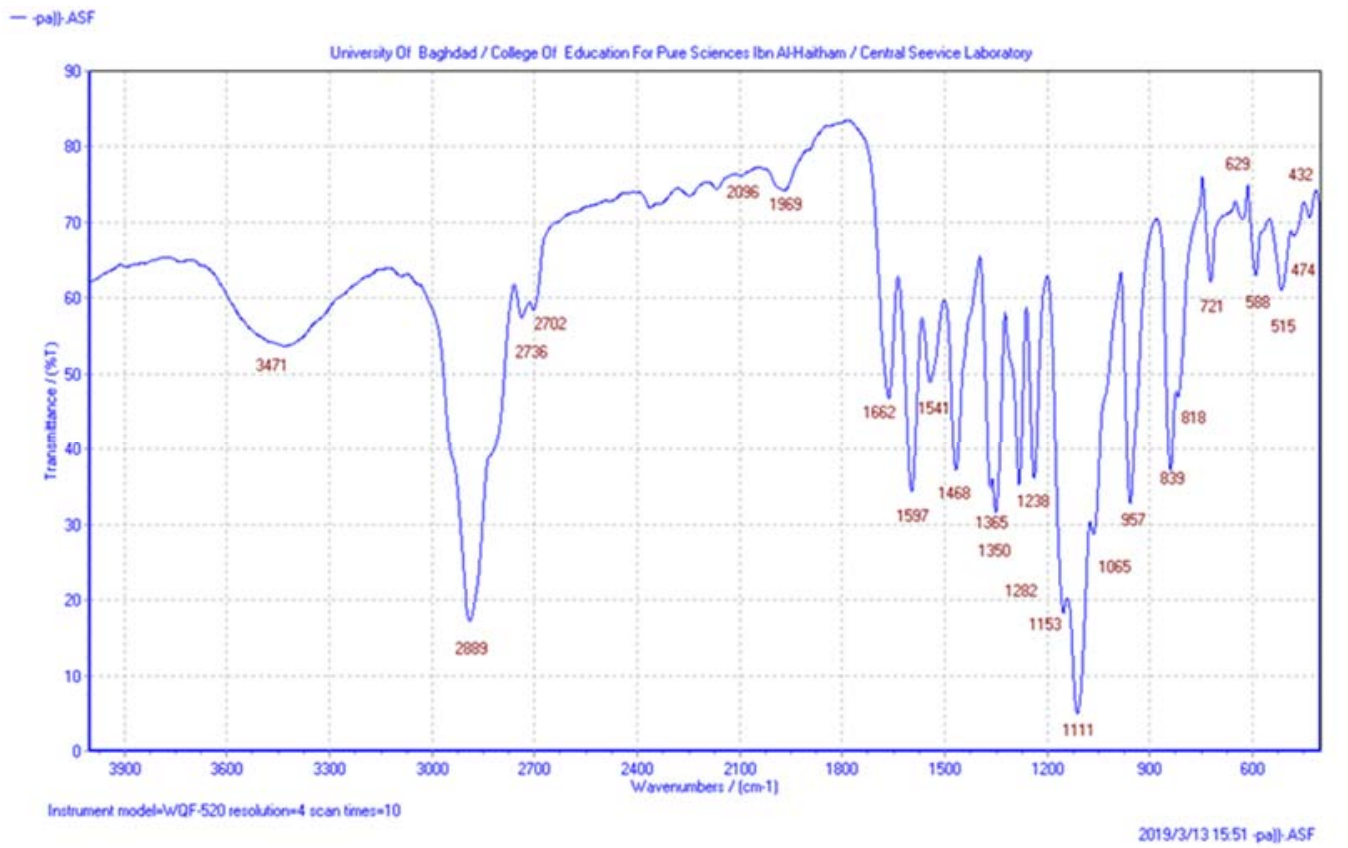

Figure 3. FTIR spectra of polycyclic acetal.

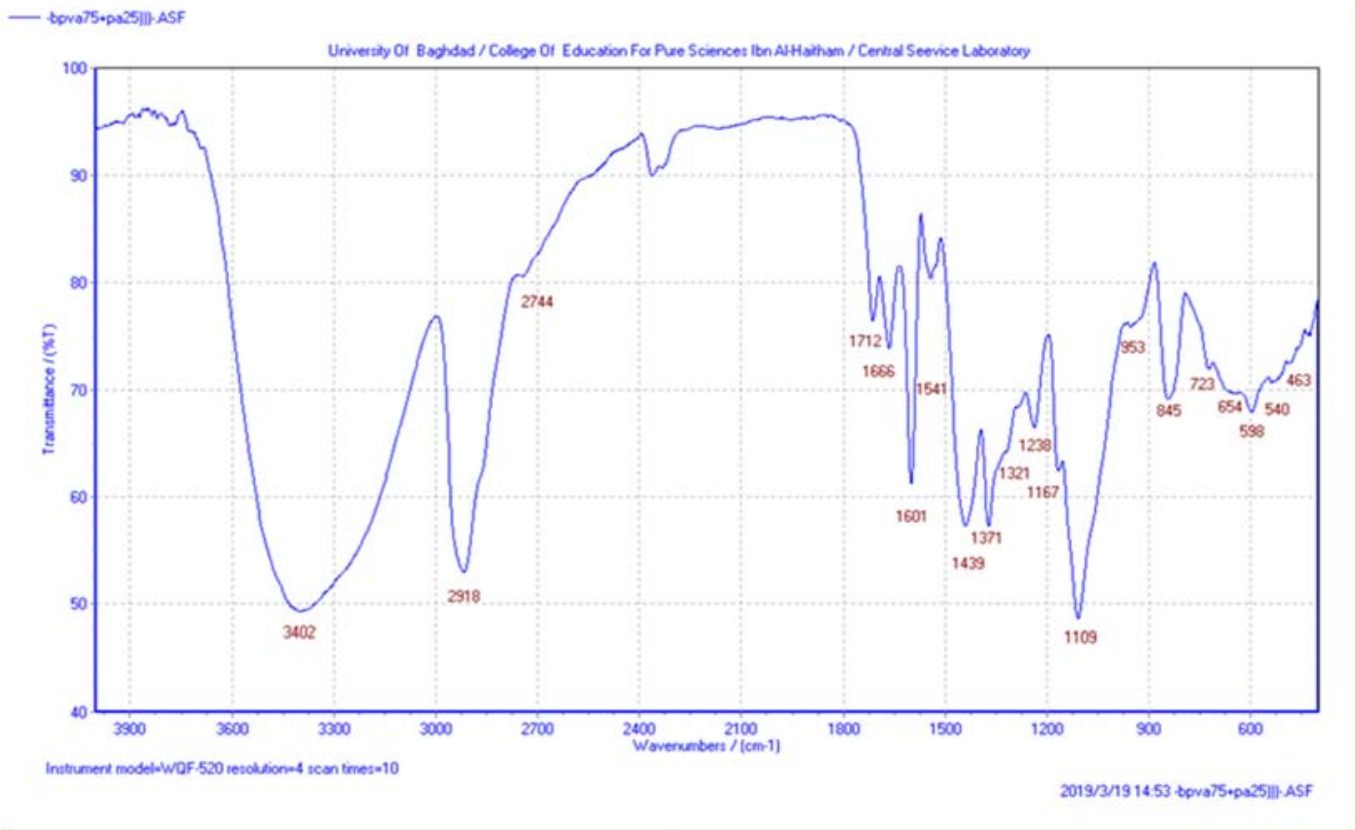

Figure 4. FTIR spectra of (PVA/PA) blend. 


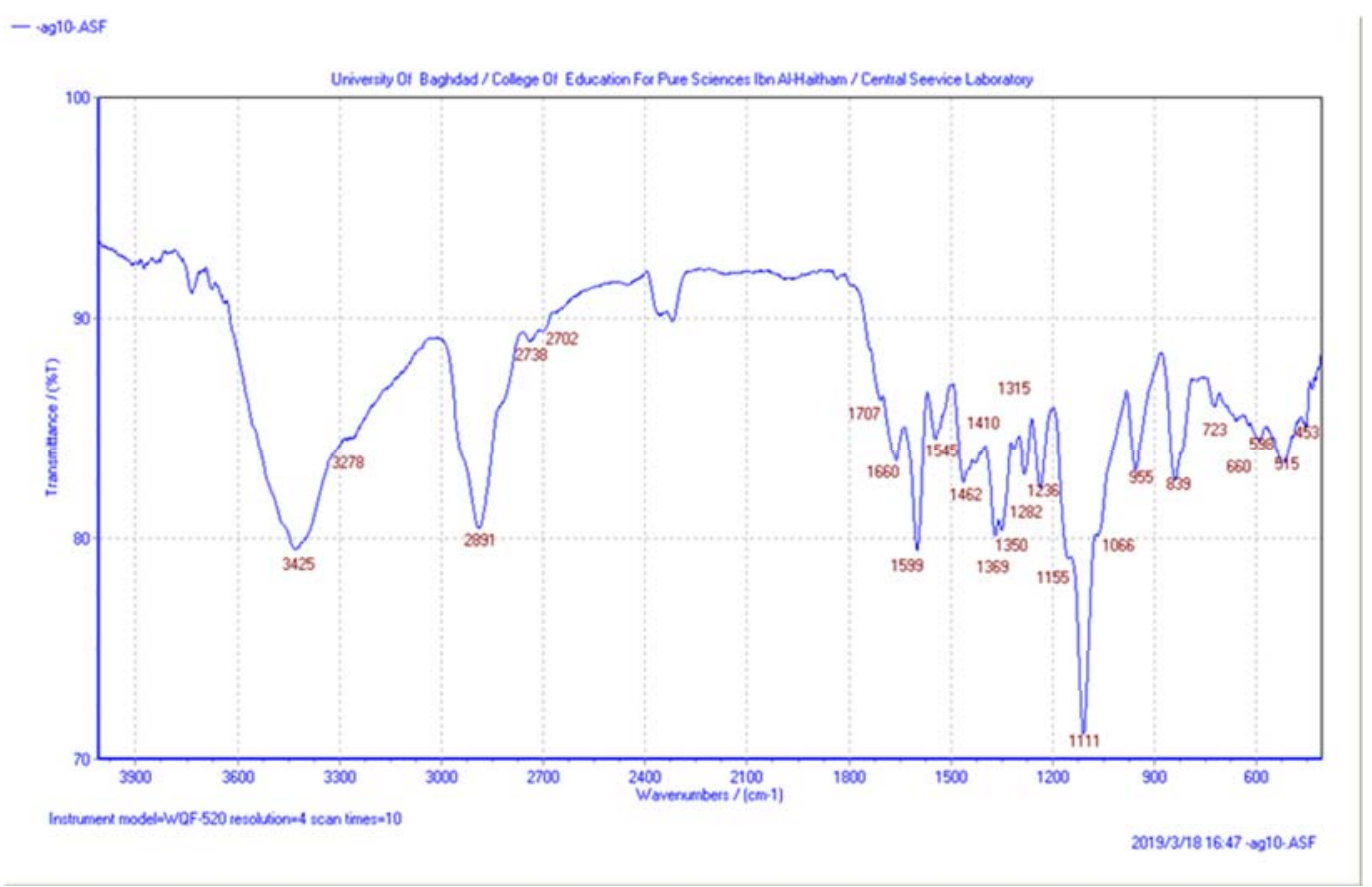

Figure 5. FTIR spectra of (PVA/PA-Ag) blend.

\subsection{Thermal analysis}

The thermo gravimetric (DSC/TGA) for the pure PVA, PA / Ag metal complex as well as the PVA/PA polymer blend was measured at temperatures in range 0 to $600{ }^{\circ} \mathrm{C}$ with constant rate of $10^{\circ} \mathrm{C} / \mathrm{min}-1$.

The TGA curve that is related to Polyacetal Figure 6. Indicates 3 steps regarding continuous mass loss. The initial step at $120-318.77^{\circ} \mathrm{C}$ with $-55.84 \%$ mass loss regarding the volatile compounds. The second step at $318.77-364.45^{\circ} \mathrm{C}$ with $-2.981 \%$ mass lose. The final step at $364.45-594.94^{\circ} \mathrm{C}$ for decomposition regarding polymer side chain as well as weight loss of approximately $-42.798 \%$

The DSC curve for the polyacetal indicated glass transition temperature $\mathrm{Tg}$ at $58.8^{\circ} \mathrm{C}$. The endothermic peak located at a $233.8^{\circ} \mathrm{C}$ related to polymer melting $\mathrm{Tm}$. Degradation temperature $\mathrm{Td}$ at a $558.7^{\circ} \mathrm{C}$.

The TGA thermo gram regarding the B(PVA/PA) Figure 7. Exhibited 3 steps. The initial one was at $100-380.43^{\circ} \mathrm{C}$ with the weight loss approximately $(-61.42 \%)$. The second step at $380.43-460.81^{\circ} \mathrm{C}$ with weight loss approximately $(-6.67 \%)$. The third step $460.81-595.24^{\circ} \mathrm{C}$ with weight loss approximately $(-8.12 \%)$.

The DSC curve of $\mathrm{B}(\mathrm{PVA} / \mathrm{PA})$ showed glass transition temperature $\mathrm{Tg}$ at $73.5^{\circ} \mathrm{C}$.The endothermic peak related to Crystalline temperature point $\mathrm{Tc}$ at $196.8{ }^{\circ} \mathrm{C}$ and $\left(390{ }^{\circ} \mathrm{C}\right)$ of melting point $\mathrm{Tm}$. Degradation temperature $\mathrm{Td}$ at $505.9^{\circ} \mathrm{C}$.

The TGA thermo gram regarding (PA-Ag) Figure 8. Was displayed in two steps. The first one was at $110-338.48^{\circ} \mathrm{C}$ with a weight loss approximately $-24.36 \%$. The last step was at $338.48-495.93^{\circ} \mathrm{Cwith}$ weight loss approximately $-61.45 \%$. 
The DSC curve of (PA-Ag) presented the glass transition temperature $\mathrm{Tg}$ at $50^{\circ} \mathrm{C}$. The endothermic peak related to Crystalline temperature point $\mathrm{Tc}$ at $240^{\circ} \mathrm{C}$ and $410^{\circ} \mathrm{C}$ of melting point $\mathrm{Tm}$. The polymer degraded at $500^{\circ} \mathrm{C}$.

The TGA thermo gram related to the B(PVA/PA-Ag) Figure 9. Was displayed in three steps. The first-step was assigned at $225-326.02^{\circ} \mathrm{C}$ with weight loss approximately $-16.70 \%$. The second step was located at $326.02-438.61^{\circ} \mathrm{C}$ with weight loss approximately $-60.35 \%$. The third step was located at $438.61-497.50^{\circ} \mathrm{C}$ with weight loss approximately $-7.56 \%$.

The DSC curve of $\mathrm{B}(\mathrm{PVA} / \mathrm{PA}-\mathrm{Ag})$ exhibited the glass transition temperature at $65.5^{\circ} \mathrm{C}$. The crystalline temperature point located at $205^{\circ} \mathrm{C}$ and $310^{\circ} \mathrm{C}$ of melting point $\mathrm{Tm}$. Degradation temperature $\mathrm{Td}$ at $400^{\circ} \mathrm{C}$.

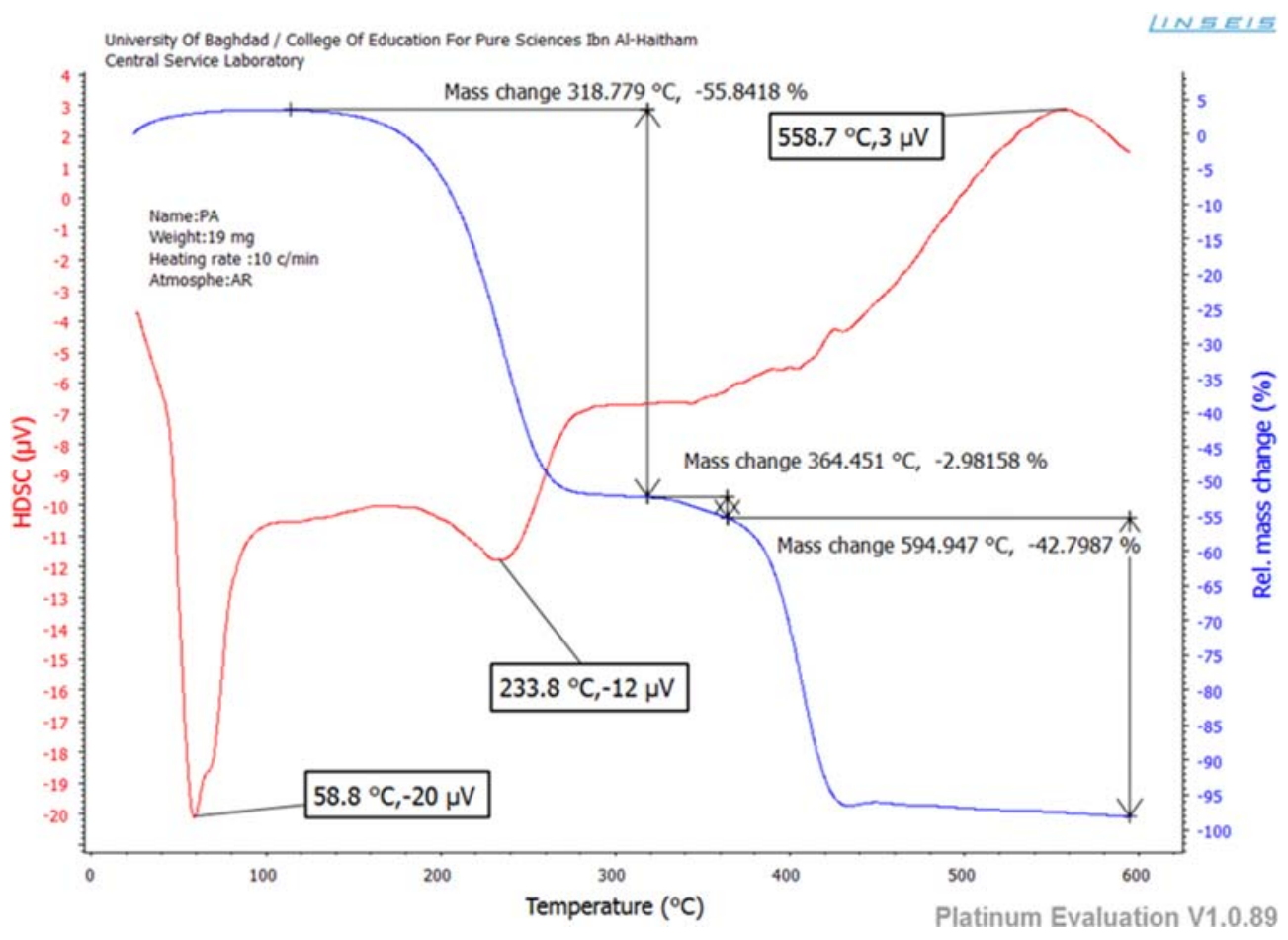

Figure 6. Thermal analysis of polycyclic acetal. 
Ibn Al-Haitham Jour.for Pure \&Appl.Sci. 33 (3) 2020

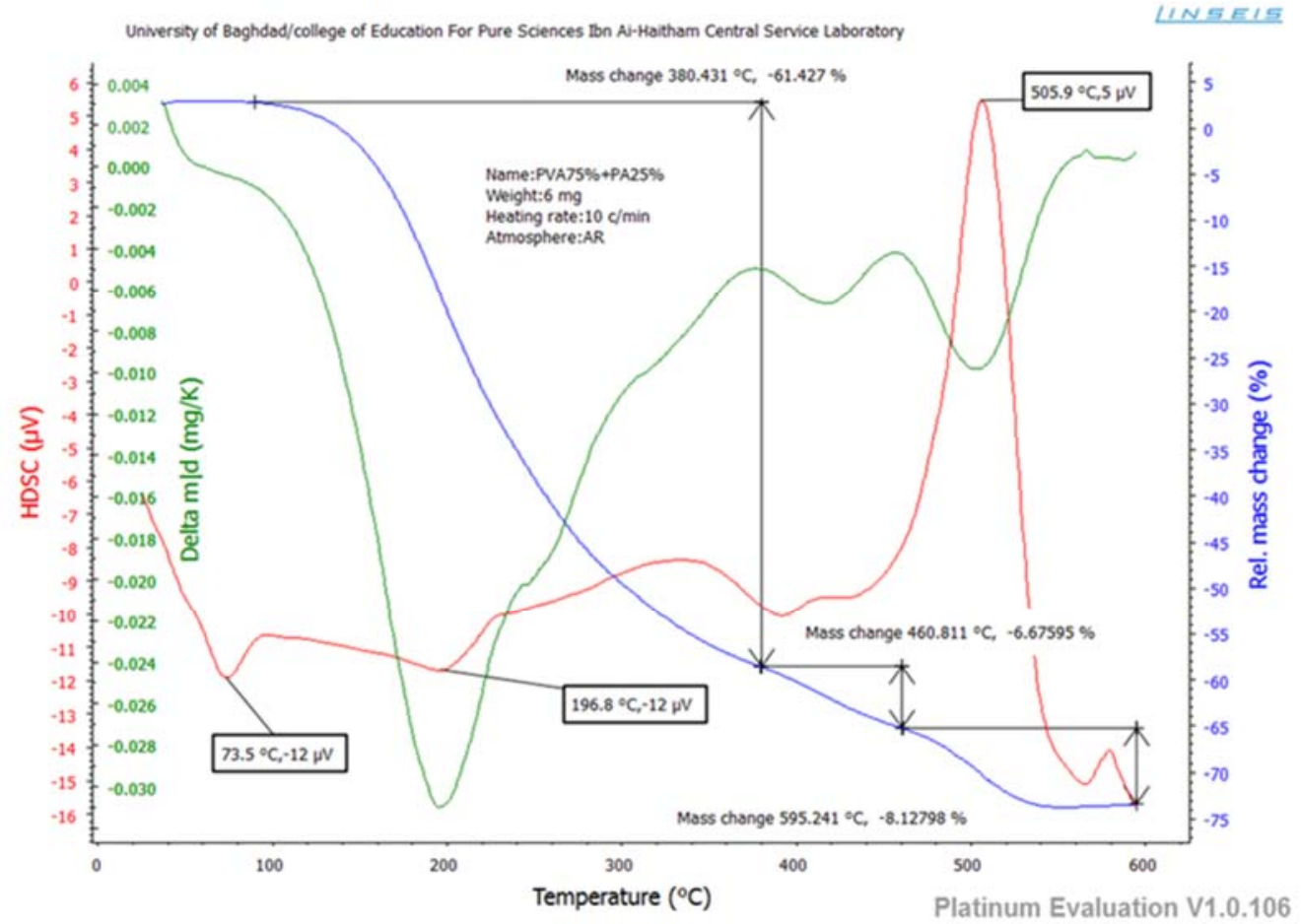

Figure 7. Thermal analysis of [PVA/PA] blend.

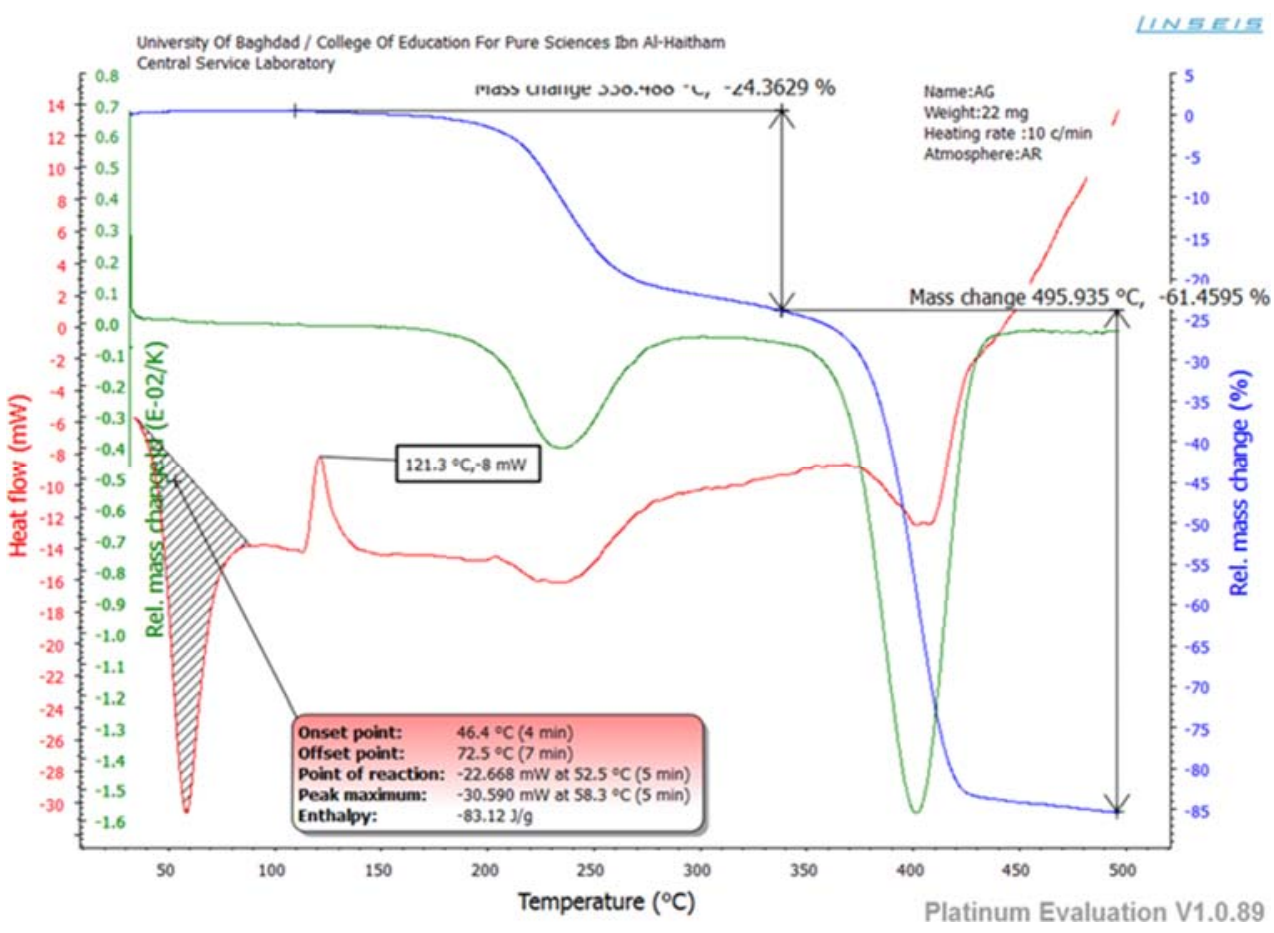

Figure 8. Thermal analysis of [PA-Ag]. 
Ibn Al-Haitham Jour.for Pure \&Appl.Sci. 33 (3) 2020

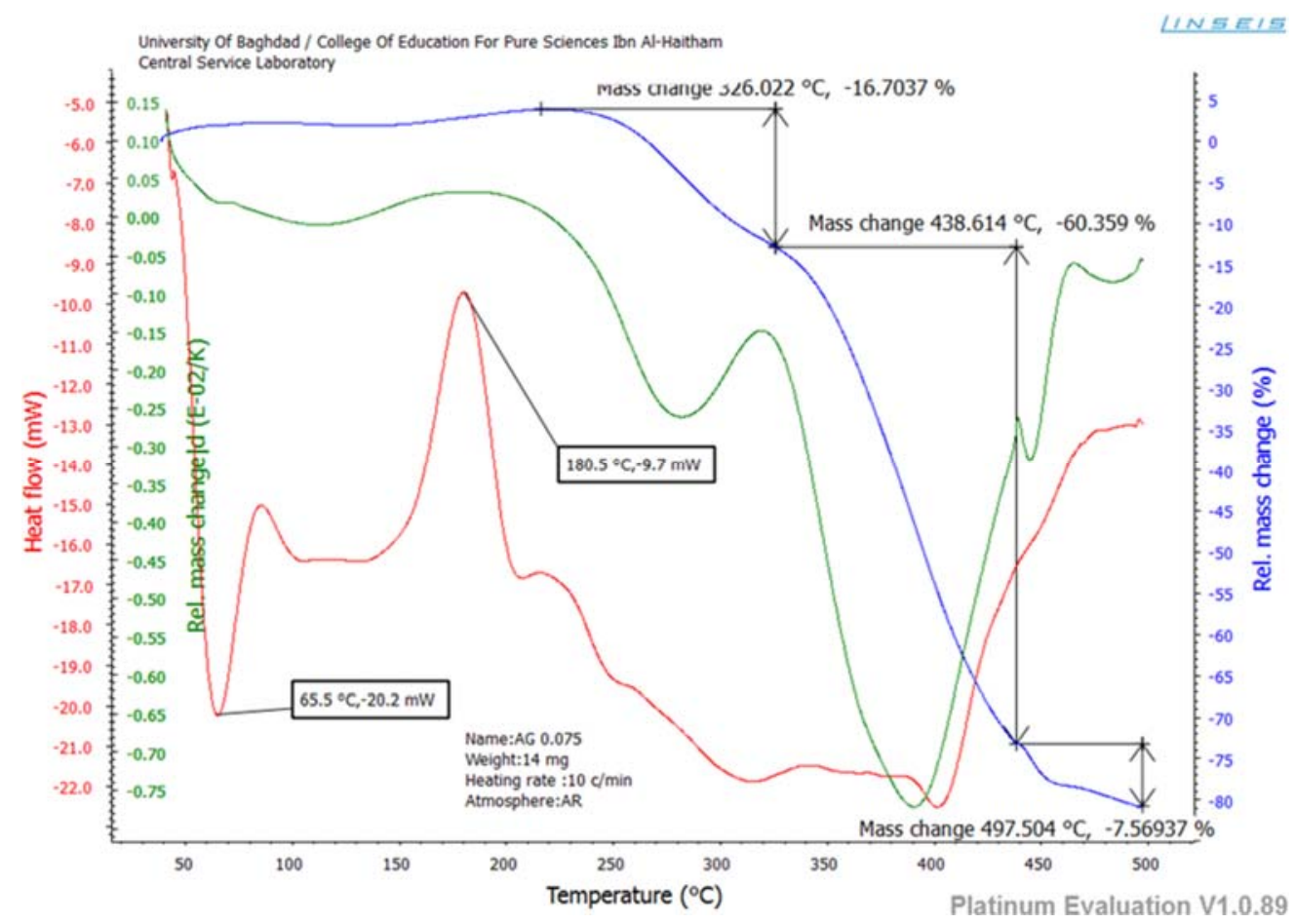

Figure 9. Thermal analysis of [PVA/PA-Ag] blend.

\subsection{Antibacterial activity}

\section{Antibacterial activity for derivative ligand $[\mathrm{PA}]$ and complexes:}

The synthesized polyacetal and its metal complex besides to PVA/PA-Ag blend have been evaluated in vitro against gram_vebacteria: E-coli,Klebsiellapneumoniae, and gram +ve Staphyloccusaureus, Bacillus subtilis .

The results of the anti-bacterial activity in Table 3. Indicated that the polyacetal and its metal complex displayed moderate to excellent activity against all kinds of bacteria [10-12]. For the polymer blends, all of the prepared blends showed a good activity against all bacteria types. The antibacterial activity was found to be in the order

$\mathrm{B} 3 \mathrm{Ag}>\mathrm{B} 2 \mathrm{Ag}>\mathrm{B} 1 \mathrm{Ag}$

Increasing the biological activities regarding metal complex may due to the effect of the metal ions on normal cell process. Potential action mode was the increase in the toxicity could be taken into account (Tweedy's chelation theory) [13]. Chelation significantly decrease metal ion polarity due to partial sharing regarding metal positive charge with donor groups as well as the potential of de-localization that was related to the p-electron in entire ring system which was created throughout coordination. This chelation might improve lipophilicity regarding central metal atom, thus increasing hydrophobic character as well as the liposolubility regarding complex preferring its permeation via cell membrane lipid layer. Such process would enhance the rate related to uptake/entrance, and therefore anti-microbial activities regarding testing compounds. Thus, anti-microbial activity related to the metal complex could be indicated to increase in lipophilicity that would be going to deactivate the respiration processes enzymes and also the other cellular enzymes, that were of high importance in the metabolic pathways regarding tested micro-organisms [14]. 
Ibn Al-Haitham Jour.for Pure \&Appl.Sci. 33 (3) 2020

Table 3. Inhibition diameter in millimeter for ligand complexes after $24 \mathrm{hrs}$.

\begin{tabular}{|c|c|c|c|c|}
\hline ComPoud & $\begin{array}{c}\text { Staphylococcus } \\
\text { aureas }\end{array}$ & Escherichia Coli & Bacillus subtilis & $\begin{array}{c}\text { Klebsiellapneum } \\
\text { oniae }\end{array}$ \\
\hline PA & - & 11 & 13 & 16 \\
\hline PA-Ag & 13 & 12 & 14 & 11 \\
\hline B1(PA-PVA) & - & - & -- & 18 \\
\hline B2(PA-PVA) & 10 & 16 & 11 & 13 \\
\hline B3(PA-PVA) & - & 13 & - & 14 \\
\hline B1(PA-Ag/PVA) & 14 & 16 & 14 & 13 \\
\hline B2(PA-Ag/PVA) & 14 & 15 & 14 & 18 \\
\hline B3(PA-Ag/PVA) & 15 & 14 & & \\
\hline
\end{tabular}

\section{Conclusion}

Polyacetal, PA-Ag and PVA/PA-Ag polymer blend were prepared through solution casting method. Thermal analysis revealed addition of PVA improves thermal stability of PVA/PA-Ag blends. Biological activity revealed that PA-Ag metal complex has the greater activity than polyacetal and polymer blend against all kinds of bacteria.

\section{References}

1. Ventola, C.L. The antibiotic resistance crisis: Part 1: Causes and threats. Pharm. Ther.2015, 40, 277-283.

2. Siedenbiedel, F.; Tiller, J.C. Antimicrobial polymers in solution and on surfaces, Overview and functional principles. Polymers.2012, 4, 1, 46-71 .

3. Kenawy, E.-R.; Worley, S.D.; Broughton, R. The chemistry and applications of antimicrobial polymers, Astate-of-the-art review. Biomacromolecules.2007, 8, 13591384.

4. Jain, A.; Duvvuri, L.S.; Farah, S.; Beyth, N.; Domb, A.J.; Khan, W.; Jain, A.; Duvvuri, L.S.; Farah, S.; Beyth, N.; Domb, A.J.; Khan, W. Antimicrobial polymers.Healthc. Mater.2014, 3, 12, 1969-1985.

5. Luo, J.; Borgens, R.; Shi, R.; Neurotrauma, J. Polyethylene glycol improves function and reduces oxidative stress in synaptosomal preparations following spinal cord injury J. Neurotrauma.2004, 21, 8, 994-1007.

6. Krauss, J., Faltermeier, A., Behr, M. and Proff, P. Evaluation of alternative polymer bracket materials. Am J OrthodDentofac.2010, 137, 3,362-367.

7. Walsh, D.; Rostami, J.S. The miscibility of high polymers: The role of specific interactions Polym Adv. Sci.1985, 70,119-169. 
Ibn Al-Haitham Jour.for Pure \&Appl.Sci. 33 (3) 2020

8. Fischer, R. F.; Curtis, W.S. Cyclic Acetal poly all ylidene oligosaccharides. U.S. patented 1965, 28, 208, 993-996.

9. Jiao, T.F.; Zhou, J.; Zhou, J.; Gao, L.; Xing, Y.; Li, X. Synthesis andcharacterization of chitosan- based Schiff based compounds with Aromatic substituent Groups.Iran. Polym. J.2011, 20, 2, 123-136.

10. Awetz, J.; A. Medical Microbiology, $4^{\text {th }}$ edition McGrawHil-USA, 2007.

11. Dhingraa, N.;Kumarb, A.;Shewetab, T.M.; Kumara, M.; Bhardwaj, T.R.Involvement of apoptosis in 17-oxo-17a-aza-D-homo-5-androsten- 3 $\beta$-yl phenyl acetate induced toxicity in mouse macrophages, Scholars Research Library.2011, 3, 1, 316-323

12. Barry, A.L. The Antimicrobic Susceptibility test principle and practices, Ann. Intern. Med.1977, 87, 3, 384-391.

13. Tweedy, B.G.Plant extracts with metal ions as potential antimicrobial agents. Phytopathology.1964, 55, 910-914.

14. Hosny, W.M.; Khalaf-Alaa, P.A.Potentiometric Study and Biological Activity of Some Metal Ion Complexes of Polyvinyl Alcohol (PVA) Int, Electrochem. Sci.2013, 8, 1520 1533. 